\title{
Główne przesłanki polityki rządu wobec energetyki w świetle Polityki Energetycznej Polski do 2040 roku. Wodór paliwem pierwszej połowy XXI wieku
}

\author{
The Main Assumptions of the Government' Energy Policy \\ in the Perspective of Energy Policy of POLAND till 2040. \\ Hydrogen as a Fuel of the First Half of XXI Century
}

\section{Andrzej Sikora}

Instytut Studiów Energetycznych

ORCID: https://orcid.org/0000-0002-0610-3583

E-mail: andrzej.sikora@ise.com.pl

\section{Mateusz Sikora}

Instytut Studiów Energetycznych

ORCID: https://orcid.org/0000-0002-8291-4468

E-mail:mateusz.sikora@ise.com.pl

Abstract

Polish Ministry of Energy has announced for consultation a draft of The Polish Energy Policy till 2040 (PEP 2040's). Authors discuss assumptions and general thesis showed by government and stated that the strategic objectives of PEP 2040's are incompatible with the European climate policy. Document don't contain criteria, policies and measures that are necessary to prepare the plan for energy and climate policy resulting from EU obligations under the Paris Agreement, which has also been ratified by Poland. Authors suggest that this document can only be considered as an introduction to the discussion. The global energy and climate policy forces to look for alternative solutions and sources of cheap electricity. We know what hydrogen is, we can accumulate and transform it into electricity. Authors hope that after reading the text in the reader's mind, the question will arise when the "hydrogen era breaks out".

Keywords - Polish Energy Policy, natural gas, hydrogen, methane, hydrates, natural gas liquids, climate changes, energy 
W listopadzie 2018 roku pojawił się, wymagany prawem energetycznym, dokument Polityka Energetyczna Polski do 2040 roku (PEP 2040) [1], w którym powinny być zdefiniowane główne założenia rządu dla polityki energetycznej w perspektywie roku 2040.

„W poczuciu humanizmu i zaangażowanie w dobrostan Ziemi, która żywi nas i pokolenia, które przyjdą po nas” [2],15 grudnia 2018 roku podpisano dokument końcowy szczytu klimatycznego ONZ w Katowicach. To po raz kolejny znak jak istotnym wydarzeniem było przyjęcie do realizacji Porozumienia Paryskiego z roku 2015 - pierwszej światowej umowy klimatyczna, która zobowiązała rządy państw-sygnatariuszy do działań na rzecz klimatu. Kraje te zobowiązały się wówczas, że podejmą działania na rzecz zatrzymania globalnego ocieplenia na poziomie dwóch stopni Celsjusza - a w razie możliwości 1,5 stopnia Celsjusza - powyżej średniej temperatur sprzed rewolucji przemysłowej [3].

29 grudnia 2018 roku prezydent Andrzej Duda podpisał ustawe przeciwdziałająca wzrostowi cen prądu w roku 2019. Nowelizacja obniża akcyzę na energię elektryczną do 5 zł/MWh z 20 zł/MWh i obniża stawki opłaty przejściowej o 95\% w roku 2019. Ustala także poziom cen i stawek opłat za przesył i dystrybucję energii na poziomie nie wyższym niż poziom z 31 grudnia2018 roku oraz stawek opłat dotyczących sprzedaży energii na poziomie nie wyższym niż poziom z 30 czerwca 2018 roku. Przedsiębiorstwa, które z tego tytułu miałyby ponieść stratę, otrzymają odpowiednie środki z Funduszu Wypłaty Różnicy Ceny [4].

14 stycznia 2019 roku na Kongresie „PowerPol” prezes Urzędu Regulacji Energetyki stwierdził, że „,[...] niedawno przyjętą ustawę, która ma przeciwdziałać wzrostowi cen prądu, trzeba szybko zmienić. Stoimy jednoznacznie na stanowisku, że ustawa wymaga bardzo pilnej nowelizacji. [...] Brzmienie ustawy jest sprzeczne $z$ innymi aktami prawnymi i daleko niejasne. [...] Nie możemy dłużej tolerować, jako odbiorcy energii, dużego zapóźnienia, jeśli chodzi o nowoczesność i dyspozycyjność energetyki. Nie unikniemy dyskusji o tym, że energia będzie drożeć” [5]. To oczywiste, ponieważ polska elektroenergetyka, w szczególności sieci przesyłowe i dystrybucyjne, wymagają wielkich nakładów inwestycyjnych (i są to programy uzgodnione z Agencją ds. Współpracy Organów Regulacji Energetyki, Urzędem Regulacji Energetyki i Komisją Europejska).

Przyjęcie ustawy, to w naszej ocenie, znaczne ograniczenie wolnego rynku energii elektrycznej. Fatalnie, że poparte praktycznie przez wszystkie siły polityczne. Nikt nie ma pojęcia, jak to będzie działać [6]. Do chwili pisania tego artykułu (koniec 
stycznia 2019 roku) Minister Energii nie wydał rozporządzeń wykonawczych. A prezes Towarowej Giełdy Energii, Piotr Zawistowski twierdzi: „Sądzimy, że już dzisiaj należy poszukiwać nowej, zdecentralizowanej koncepcji handlu energią w Polsce umożliwiającej bilansowanie lokalne podaży i popytu na energię. TGE z dużym zainteresowaniem obserwuje pilotażowe działania w tym zakresie (oparte na technologii blockchain), jakie prowadzone są obecnie w Europie. Niezależnie od tego oczekujemy również zmian na obecnym rynku bilansującym” [7].

Prezes Piotr Zawistowski ocenia, że w dłuższej perspektywie czekają nas radykalne zmiany na rynku energii z uwagi na rosnący udział energetyki rozproszonej, czy to związany z rozwojem odnawialnych źródeł energii (OZE), czy małej kogeneracji gazowej. W związku z powyższym nieuniknione będzie stopniowe przenoszenie ciężaru i odpowiedzialności za bilansowanie podaży i popytu na energię z poziomu sieci przesyłowej, na obszar sieci dystrybucyjnych.

15 stycznia 2019 roku mijał termin zarządzonych przez Ministra Energii konsultacji nad opublikowaną PEP 2040. Lektura pozwala na stwierdzenie, że strategiczne cele PEP 2040 są niezgodne z europejską polityką klimatyczną [8]. Co więcej, już wiadomo, że Polska nie zrealizuje założonego celu 15\% udziału energii ze źródeł odnawialnych w ogólnym zużyciu energii brutto w roku 2020. Już w sierpniu 2018 roku Najwyższa Izba Kontroli opublikowała raport, z którego wynikało, że osiagnięcie przez Polskę założonego celu 15\% udziału energii ze źródeł odnawialnych w ogólnym zużyciu energii brutto w roku 2020 może być zagrożone [9]. W listopadzie tego samego roku Główny Urząd Statystyczny poinformował, że udział energii z OZE w końcowym zużyciu energii brutto w Polsce spadł w roku 2017 o 0,32 pkt proc., do 11\% [10]. Brakującą energię z OZE będziemy musieli kupić w tych państwach, które swoje cele spełnią, może to kosztować nawet 50-100 euro za MWh.

Przyjrzyjmy się dokładniej dokumentowi (a może lepiej: esejowi) Polityka Energetyczna Polski do 2040 roku.

PEP 2040 zawiera opis stanu wyjściowego, dokonany praktycznie bez jakichkolwiek istotnych liczb oraz obraz polskiej energetyki, podzielonej na kilka podstawowych obszarów (choć nie ma tam na przykład słowa o energii generowanej z wody).

\section{Czego w PEP 2040 brakuje:}

- Odniesień do sytuacji międzynarodowej. Jedyne, o czym jest mowa, to cele Unii Europejskiej na rok 2020 i stwierdzenie, że kolejne cele (na lata 2030 i 2040) nam 
nie odpowiadają i będziemy przekonywać Unię do naszych opinii. Ponadto nie zgadzamy się na Nord Stream 2. Cała polityka energetyczno-klimatyczna Unii Europejskiej, pakiet zimowy itd., cała „reszta świata” nie istnieje, co więcej, omawiany dokument (esej) traktuje rzeczywistość (chyba) jako niezmienną od XIX wieku. Co z ociepleniem klimatu, migracjami, sytuacja polityczna, wyczerpywaniem się złóż kopalin? Nie wiadomo. Odpowiedzi na to nie ma...

- Odwołań do sytuacji w Polsce, oprócz stwierdzenia, że węgiel i „,węglowe” miejsca pracy są ważne. Ale np. mamy zbudować elektrownię jądrową w roku 2033, przy czym już ją budujemy od 10 lat i stale brak jakiegokolwiek efektu. Co ciekawe, prócz dyskutowanych od dłuższego czasu lokalizacji na wybrzeżu (Kopalino lub Żarnowiec) pojawia się także nieokreślona lokalizacja w centralnej część Polski (okolice Bełchatowa) [11].

- Przydałaby się analiza, dlaczego stale stoimy w miejscu i dlaczego teraz „ruszymy z kopyta". Takich refleksji nie ma, ale - zdaniem autorów PEP 2040 - będziemy budować wysokotemperaturowe reaktory (ang. High Temperature Reactor - HTR).

- W roku 2040 mamy generować $60 \%$ energii elektrycznej z węgla. Jak na to zareaguje UE (i reszta świata) i jak to wpłynie na konkurencyjność polskiej gospodarki? Kto sfinansuje inwestycje węglowe? Gdzie znajdziemy te pokłady do efektywnego eksploatowania? Brak nawet pytań, zatem nie dziwi brak odpowiedzi.

- Analiz dotyczacych ropy i logistyki ropy naftowej. Zgodnie z wytycznymi zawartymi w PEP 2040, wszystkie aktywa logistyczne powinny być w jednym podmiocie państwowym. A jak dobrze wiemy, PKN Orlen miał sprzedać wszystkie aktywa logistyczne do PERN SA do listopada 2018 roku. Nie sprzedał. I co? I nic.

- Nigdzie w dokumentach (PEP 2040 i Wnioski z analiz prognostycznych dla sektora energetycznego [12]) nie pojawia się odniesienie do cen ropy naftowej (które nadal pozostaja głównym wyznacznikiem pośrednio wpływającym na mix energetyczny), nie ma również podanej analizy cen oraz samych prognoz.

- Skąa weźmiemy paliwa kopalne? Odpowiedź w stylu „będziemy efektywnie eksploatować złoża węgla kamiennego i brunatnego (wymieniono trzy złoża perspektywiczne, ale jak rozpocząć w nich eksploatację przy sprzeciwie ludności miejscowej, braku środków finansowych) i znajdziemy nowe złoża gazu ziemnego” jest skrajnie niepoważna. Ale jest tylko taka. Gaz ziemny będzie z Baltic 
Pipe i terminala LNG. No i z własnych złóż, również z zagranicznych. O cenach i ilościach nie wiadomo nic.

- Odnośnie odnawialnych źródeł energii, to wiadomo tylko tyle, że fotowoltaika, farmy wiatrowe na morzu i spalanie biomasy - ale nie lasów. O wiatrakach na lądzie ani słowa. Generalnie mamy wspierać źródła przewidywalne, a OZE powinno się bilansować samo na obszarze klastrów. I tylko takie samobilansujące się źródła będziemy wspierać. Tylko kto je wymyśli?

- Według PEP 2040 będziemy liberalizować rynki energii i gazu. Ale zgodnie z tym, co napisane, to już prawie wszystko zliberalizowaliśmy. Tylko pożądanych efektów brak, bo wszystko państwowe i konkurencyjność słabo się rozwija. Ale o tym cisza.

Brak jest jakichkolwiek kwantyfikacji kamieni milowych. Mamy stan początkowy i końcowy (opisowo), ale w jakich krokach dojdziemy z jednego miejsca do drugiego - nie wiadomo. Żadnych tabelek z liczbami, ścieżek cenowych, ilości produkowanej energii, mocy w systemie, zużywanych paliw. W porównaniu do PEP z roku 2009 [13] - dramat. Ale w efekcie trudno będzie sprawdzić, czy podążamy w dobrym tempie i we właściwa stronę. Może o to chodzi?

Brak opisu sposobów na osiagnięcie stawianych celów. Np. w obszarze OZE mamy rozwijać fotowoltaikę. Ale jak? Chwilowo regulacje prawne nie sprzyjają fotowoltaice. Czy cokolwiek będziemy robić - nie wiadomo. Analogicznie z elektromobilnością: mamy dziś ok. 500 samochodów, w roku 2020 ma ich być 50 tys., a w 2025 - już 1 mln. Ale w jaki sposób? Jak skłonimy ludzi do kupowania „elektrowozów”? Ani słowa.

Brak powiązań między poszczególnymi obszarami. Np. elektromobilność jest wymieniana w trzech obszarach: wytwarzania energii elektrycznej, transporcie i OZE. Ale jakie są wzajemne powiązania, tego nikt nie tłumaczy.

Brak jest również słowa o czystych technologiach węglowych. Próba zgłoszenia poprawek i zmian do PEP 2040 doprowadziła do konkluzji, że łatwiej napisać nowy dokument.

„»Projekt PEP 2040« przedstawiony w dniu 22 listopada 2018 r. jest dokumentem, który powstał w ramach zadań Ministra Energii wynikających z art. 12 ust. 2 pkt 1) ustawy Prawo energetyczne tj. przygotowania polityki energetycznej państwa. Celem polityki energetycznej państwa jest (i) zapewnienie bezpieczeństwa energetycznego kraju, (ii) wzrostu konkurencyjności gospodarki i (iii) jej efektywności energetycznej, a także (iv) 
ochrona środowiska. Elementy polityki energetycznej Państwa to (1) bilans paliwowoenergetyczny kraju (w tym jego prognoza), (2) zdolności wytwórcze krajowych źródeł paliw i energii, (3) zdolności przesyłowe, w tym połączenia transgraniczne (co najmniej do poziomu celów uzgodnionych w ramach współpracy w UE), (4) efektywność energetyczna gospodarki, (5) działania w zakresie ochrony środowiska tj. obniżenia emisji szkodliwych substancji ( $z$ uwzględnieniem poziomu maksymalnych emisji uzgodnionego w ramach współpracy w UE), (6) rozwój wykorzystania instalacji odnawialnych źródeł energii (co najmniej do poziomu celów uzgodnionych w ramach współpracy w UE), (7) wielkości i rodzaje zapasów paliw (w tym prognoza cenowa), (8) kierunki restrukturyzacji i przekształceń własnościowych sektora paliwowo-energetycznego, (9) kierunki prac naukowo-badawczych, (10) współpraca międzynarodowa w szerokim kontekście.

Polityka energetyczna państwa powinna być opracowywana co 4 lata zgodnie z zasadą zrównoważonego rozwoju kraju i zawierać: po pierwsze ocenę realizacji polityki energetycznej państwa za poprzedni okres tj. okres ośmiu lat od 2010 do 2017 r. na podstawie dokumentu pt. »Polityka Energetyczna Polski do 2030 roku« uchwalonego przez Radę Ministrów w dniu 10 listopada 2009 r. (PEP 2040 zawiera szkic tej części pt. »opis stanu i uwarunkowania«), po drugie część prognostyczną obejmująca okres nie krótszy niż 20 lat (PEP 2040 zawiera część prognostyczna, przy czym założenia jak np. bilans paliwowo-energetyczny lub ścieżki cen sa nieznane), oraz po trzecie program działań wykonawczych na okres 4 lat, zawierający instrumenty jego realizacji (PEP 2040 zawiera wyłącznie garstkę informacji odnośnie instrumentów jego realizacji w najbliższym horyzoncie czasowym). Można dojść do wniosku, że dokument PEP 2040 zawiera w istocie wyłącznie część prognostyczną obejmująca okres do 2040 r. i w związku z tym jest wattpliwe czy spełnia wymogi ustawowe polityki energetycznej państwa”[14].

Polsce brakuje modelu prognozowania gospodarki, ale także modelu dla prognozowania polityki energetycznej państwa.

Dokument PEP 2040 nie spełnia wymogów polityki energetycznej państwa, ani zintegrowanej strategii sektorowej zgodnie z Strategią Odpowiedzialnego Rozwoju, która powinna służyć do przygotowywania Umowy Partnerstwa z Unią Europejską dla następnej perspektywy budżetowej. PEP 2040 nie zawiera kryteriów, polityki i środków, które są niezbędne do przygotowania Krajowego planu na rzecz energii i klimatu (KPEiK) [15], tj. planu w zakresie polityki 
energetyczno-klimatycznej wynikającej z zobowiązań unijnych z porozumienia z Paryża, które zostało również ratyfikowane przez Polskę. W związku z tym PEP 2040 może kwalifikować się jedynie jako wstęp do dyskusji. PEP 2040 niestety kwestionuje obowiązujące zobowiązania unijne i równiė̇ polski wkład do porozumienia paryskiego.

No i 15 lutego 2019 roku mija termin do konsultacji w/w projektu Krajowego planu na rzecz energii i klimatu na lata 2021-2030 [16]. Znowu opublikowanego przez Ministerstwo Energii. Oba dokumenty wydają się być rozłączne, znacząco się różnią, mimo że były przygotowywane równolegle przez to samo ministerstwo. Propozycja przedstawiona Komisji zakłada mniejszy udział węgla, większy gazu oraz mniejsze zużycie energii. Ma tak ma być, mimo, że oba dokumenty przygotowywano w oparciu o podobne prognozy?

Z perspektywy autorów od lat działających w obszarze szeroko pojętej energetyki, podstawowa sprawa do załatwienia to oczywiście stabilna - ponadpartyjna - polityka gospodarcza, z której wypływa polityka energetyczna. Nie może być dysonansów nie tylko pomiędzy ministrami w tej sprawie, ale między ugrupowaniami politycznymi. Marzy nam się ponadpartyjna polityka gospodarcza, z której wynika jasna, długofalowa polityka energetyczna - bez koniunkturalizmów i małostkowości. W tym kontekście ciagle niezałatwiona sprawa pozyskiwania gruntów pod inwestycje liniowe - czyli projekt ustawy o strategicznych inwestycjach celu publicznego.

Ale są też inne zagadnienia, bez których trudno opisać politykę energetyczną:

A) brak modelu czy narzędzia, w oparciu o które można symulować i liczyć różne scenariusze, warianty i w miarę szybko przewidywać zmiany;

B) programowo założona skromność prognoz (a raczej ich brak), w oparciu o które powstawała nowa PEP 2040.

Zbudujmy zatem ten Model prognostyczny.

Konieczne jest przygotowanie zespołu zintegrowanych narzędzi informatycznych: baz danych (hurtownia danych), modeli obliczeniowych oraz arkuszy prezentacyjnych wraz z interfejsem do ich obsługi - zwanych dalej „Modelem”. Ma on umożliwić tworzenie, analizę i prezentację scenariuszy rozwoju i optymalizacji źródeł zasilenia (rynków energii) dla gospodarki narodowej. Przykładowa architektura modelu mogłaby wyglądać tak jak na rysunku 1. 


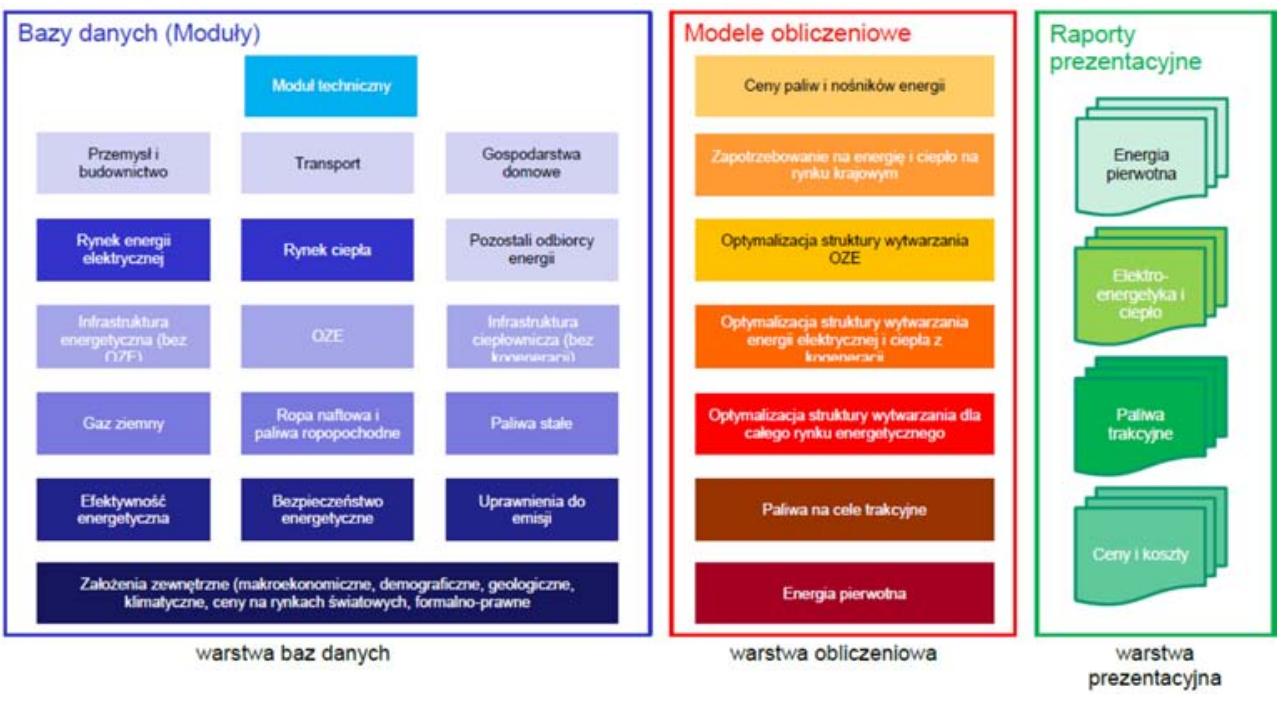

Rysunek 1. Przykładowa architektura modelu prognostycznego

Źródło: Opracowanie własne.

Tak zbudowane narzędzie winno opisywać zaistniałe lub zmieniane pod wpływem parametrów zewnętrznych interakcje pomiędzy rynkiem energii w Polsce, a następującymi elementami:

- gospodarką (opisana przy pomocy odpowiednich parametrów),

- światowym rynkiem energii (zmianami cen energii z importu),

- a także kryterialnymi parametrami środowiska naturalnego i związanymi z tym regulacjami.

Docelowo Model ma wspierać procesy decyzyjne dotyczące:

- kształtowania się najbardziej optymalnych scenariuszy rozwoju źródeł zasilenia (rynków energii) w Polsce,

- wpływu wprowadzanych regulacji unijnych i ich transpozycji krajowych na strukturę i koszty rozwoju źródeł zasilenia (rynków energii).

- polityki energetycznej Państwa wspierającej najbardziej pożądane kierunki zmian i przekształceń źródeł zasilenia (rynków energii) w Polsce.

Ale czy to wszystko jest tylko marzeniem? 


\section{Wodór paliwo - energetyczny mostem cywilizacji galaktycznej}

Otaczający nas kosmos zaledwie w kilku procentach składa się z materii, którą znamy z doświadczenia i z tablicy Mendelejewa. Około 5\% tego, z czego zbudowany jest Wszechświat, składa się z atomów - o których uczymy się w szkole - tworzących gwiazdy, mgławice, planety, otaczające nas dobra materialne, a także nas samych. Pozostałe ok. $95 \%$ wszechświata to „materia”, której obecność możemy stwierdzić tylko pośrednio - poprzez fale grawitacyjne i ich wpływ na ruchy czarnych dziur na przykład czy gwiazd i galaktyk. To tzw. ciemna materia niebarionowa (tej jest ok. 23\%) i ciemna energia $(72 \%)$.

W tych pięciu procentach najwięcej (aż 4/5) jest wodoru i helu występujących w proporcji 3:1. Reszta to neutrina, ciężkie elementy, gwiazdy, które widzimy na niebie. Ziemianie zostali wyróżnieni w zaskakujący sposób powszechnym dostępem do wodoru, z którego zbudowana jest woda i powszechnie znane i wykorzystywane przez nas węglowodory (ropa naftowa). Użycie technologii szczelinowania hydraulicznego, znanej jeszcze przecież w latach 40. zeszłego wieku, udoskonalenie i dostosowanie jej do warunków geologicznych, zmieniło światowe rynki węglowodorów. Ostatnie lata przyniosły diametralne zmiany w optyce wydobycia, ale i handlu węglowodorów. W czerwcu 2018 roku wydobycie ropy naftowej w Stanach Zjednoczonych sięgnęło 10,7 mln baryłek dziennie [16]. I ta wzrostowa tendencja wydobycia ropy i węglowodorów w USA (ale nie tylko bo Australia, bo Argentyna, nawet Chiny) nadal trwa. Prognozy przewiduja, że globalny popyt na gaz ziemny szybko rośnie, ale dramatycznie szybko rośnie podaż tzw. NGL - ang. natural gas liquid.

Ale koniecznie trzeba również wspomnieć o hydratach metanu.

13 marca 2013 roku może stać się datą przełomową dla światowej energetyki. Tego dnia w oficjalnym komunikacie Japan Oil, Gas and Metals National Corporation (JOGMEC), japońska państwowa firma, poinformowała o sukcesie pierwszej na świecie próby wydobycia gazu z hydratów metanu, dodając, że eksploatacja znajdujących się $50 \mathrm{~km}$ od japońskiego wybrzeża złóż hydratów może rozpocząć się w ciagu najbliższych 6 lat. Oznaczało to, że technologia wydobycia gazu ziemnego z hydratów metanu została opanowana i kolejnym etapem jest próba jej przemysłowej implementacji i dalej komercjalizacji. 


\section{1 mol metanu na 5,75 mola wody}

Hydrat metanu to zwykła krystaliczna struktura cząsteczek wody, w środku której uwięziona jest cząsteczka metanu.

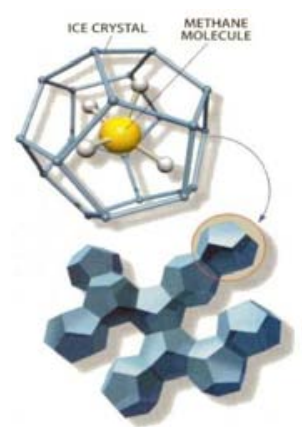

Rysunek 2. Poglądowe przedstawienie cząsteczki hydratu metanu

Źródło: [17].

Hydraty powstają wtedy, gdy cząsteczki wody łączą się wzajemnie - przy odpowiednio niskiej temperaturze i wysokim ciśnieniu - poprzez wiązania wodorowe i formują wnęki zajmowane przez pojedyncze cząstki gazu (hel, metan). Jeżeli „uwięzioną” cząsteczką jest cząsteczka metanu, mamy do czynienia z hydratami metanu. Średnio struktura hydratu zawiera 1 mol metanu, na każde 5,75 mola wody, jakkolwiek jest to zależne od tego, jak wiele cząstek metanu „pasuje” do różnych struktur wnęki utworzonej przez wodę. Nie są to stechiometryczne krystaliczne związki włączeniowe zaliczane do tzw. klatratów, czyli struktury nadcząsteczkowej, w której występuje regularna sieć krystaliczna jednego związku chemicznego, a w niej nieregularne rozmieszczone innej cząsteczki (najbardziej znane połączenia klatratowe to połączenia wody $z$ helowcami (gazami szlachetnymi) oraz wody z metanem - hydrat metanu).

Obserwowana gęstość hydratów metanu wynosi ok. $0,9 \mathrm{~g} / \mathrm{cm}^{3}$, a jeden litr w stanie stałym zawiera średnio 168 litrów metanu. Hydraty metanu występują w płytkiej litosferze (do 2000 m głębokości). Jednak odpowiednie warunki do ich formowania się występuja albo w skałach osadowych usytuowanych w obszarach polarnych, gdzie temperatury na powierzchni sa poniżej $0^{\circ} \mathrm{C}$, albo w oceanicznych skałach osadowych na głębokościach powyżej $300 \mathrm{~m}$, gdzie temperatura wody wynosi ok. $2^{\circ} \mathrm{C}$ (rysunek 3). 


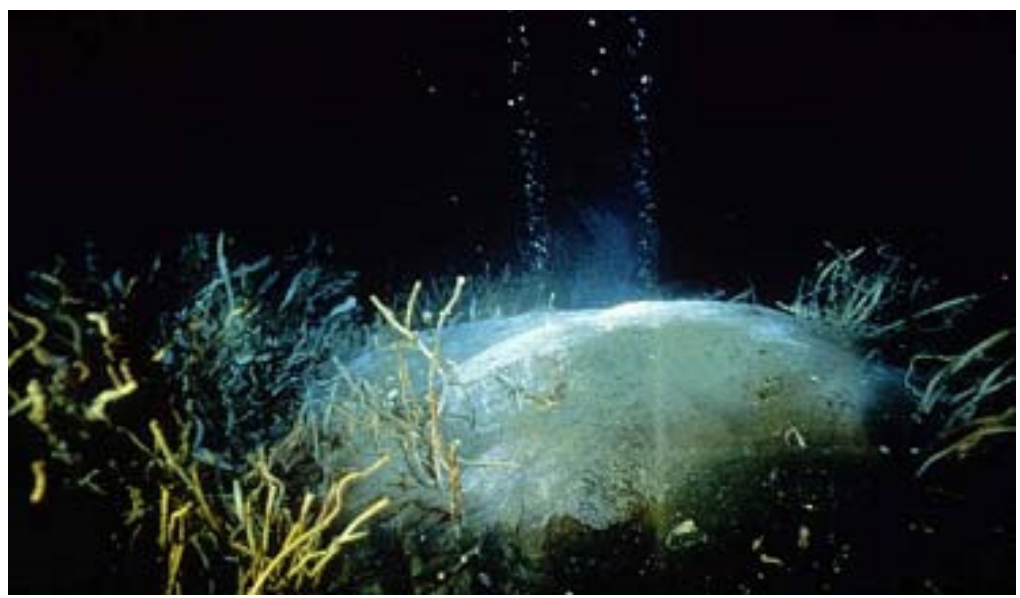

Rysunek 3. Zdjęcie podwodne kopca hydratu metanu. Widoczna dyfuzja cząsteczek metanu Źródło: [18].

\section{Kontynentalne depozyty}

Złoża hydratów ulokowane są w piaskowcach na Syberii i Alasce, na głębokościach do 800 metrów. Depozyty oceaniczne występują w kontynentalnym szelfie w skałach osadowych albo na styku skał i wody. Rezerwy hydratów metanu zawarte w skałach osadowych (zarówno oceanicznych, jak i kontynentalnych) zawierają według różnych szacunków od 2 do 10 razy więcej gazu, niż obecnie znane rezerwy konwencjonalnego gazu ziemnego (ostatnie estymacje od 1000000 do $5000000 \mathrm{mld} \mathrm{m}^{3}$ ). Oznacza to, że możliwe wydobycie tylko ok. $5 \%$ tych zasobów byłoby jest większe, niż wszystkie dotychczas znane i zdefiniowane zasoby światowe konwencjonalnego gazu ziemnego.

Dotychczasowe próby wydobywania i badania (prowadzone od lat 60. ubiegłego wieku - Syberia; 1981 - wydobycie próbek w Gwatemali, statek wiertniczy Glomar Challanger) - skazane były na niepowodzenie. Hydrat metanu zwany też metanowym lodem, poznany został już w latach trzydziestych XX wieku. Wtedy to E.G. Hammerschmidt skojarzył po raz pierwszy biały, krystaliczny materiał zatykający gazociagi z hydratami metanu. Próby jego wydobycia $z$ dna mórz trwają od kilkunastu lat w wielu bogatych krajach, które nie skąpią środków na badania związane z energetyką. 
Ale hydraty to ciagle jeszcze przyszłość (pewnie bliższa nawet niż się nam wydaje). Tą najbliższą są naturalne gazy płynne (ang. Natural Gas Liquids - NGL), czyli metan, etan propan, butan, produkty stowarzyszone przy wydobyciu ropy naftowej - aż chce się powiedzieć produkty „zbędne” dla rynku ropy naftowej! Ale wyobraźmy sobie propan czy butan (czyli LPG - ang. Liquid Petroleum Gas - czyli dotychczas produkty rafineryjne!) otrzymujemy z wydobycia, z upstream, czyste i „darmowe”. A to podstawowe surowce dla petrochemii (linia propan, propylen, polipropylen; etan, etylen, polietylen) i dodatkowe źródło wodoru (metan cztery cząsteczki wodoru, etan sześć cząsteczek wodoru itd.)

Czy doczekamy chwili, kiedy na molekularnych sitach w obecności katalizatora będzie możliwy rozkład cząsteczki wody (metanu; etanu; propanu - niepotrzebne skreślić) do tlenu i wodoru? Analogicznie do tego, jak dziś w każdej szkolnej sali dokonujemy elektrolizy wody - tyle tylko, że ten proces wymaga dużo więcej energii niż ta, która mogłaby być otrzymana z wodoru - bo to reakcja z ujemnym bilansem energetycznym.

Mówiąc o elektrolizie nie można zapomnieć o metodzie PEM (ang. Polymer Electrolyte Membrane) stanowiącej alternatywę dla mało efektywnej, lecz tańszej metody (ang. Alkaline Water Electrolysis). Jedyna, lecz decydująca wadą PEM jest jej wysoki koszt. Spekulując można próbować obniżyć koszty tejże metody poprzez zastapienie platyny grafenem w roli katalizatora.

Światowa polityka energetyczno-klimatyczna zmusza do szukania alternatywnych rozwiązań i źródeł taniej energii elektrycznej. Priorytetowe zdają się być aspekty magazynowania i przesyłu wodoru na skale przemysłową oraz optymalizacja procesu jego otrzymywania (produkcji?). Wiemy, czym jest wodór [19; 20], znamy jego właściwości, potrafimy zgromadzić i przeobrazić w energię elektryczną. Idee jego magazynowania rozwijają się w dynamicznym tempie.

Mamy nadzieję, że po lekturze tego tekstu w umyśle Czytelnika zrodzi się pytanie o termin wybuchu ery wodoru. W naszej opinii ten okres rozpoczął się już w drugiej dekadzie XXI wieku. Setki artykułów dotyczących możliwości wykorzystania pojazdów mechanicznych napędzanych wodorem, planowanych stacji tankowania wodoru czy budowy podziemnych magazynów $\mathrm{H}_{2}$ w kawernach solnych to przesłanka. Może jednak wystarczy, aby ktoś położył się pod jabłonią albo wszedł do wanny z wodą i wykrzyknął „Eureka”! Hasło na dziś: wdrożyć rewolucję grafenu i OZE w erę wodoru! 
Ekonomia w tym ujęciu to nastawianie się na optymalizację procesów produkcji, magazynowania i przesyłu wodoru na skalę przemysłową. Kluczem może być tzw. węza - zaczyn chemicznego plastra miodu - grafen. A może przyszłość należy do sorbentów o wysokiej wydajności?!

Zrozumienie swojej pozycji w otoczeniu, w gospodarce, wobec obszaru szeroko pojętej energii, klimatu, surowców i technologii ma istotne znaczenie. Każdy z nas ma do spełnienia olbrzymią rolę w przemianie gospodarki świata. Magazyny energii, nowe materiały (grafen), nadprzewodnictwo w temperaturze pokojowej, farmaceutyka molekularna, aby wymienić kilka. Ważne jest, aby przynajmniej próbować wejść silniej w obszar innowacji, nowoczesnych technologii, nowych rozwiązań, aby nie zostać w pozycji gospodarczego, energetycznego zaplecza (także surowcowego z węglem na czele). Ważne jest, aby móc zrewolucjonizować system wsparcia nie tylko finansowego dla nowatorskich idei, pomysłów, ale przede wszystkim naukowego, aby nasi młodzi pasjonaci mogli uczestniczyć, tworzyć, odkrywać nowe oblicze Ziemi.

Jako ludzkość stoimy na rozdrożu. Z jednej strony trudno sobie wyobrazić życie bez energii, ale równie trudno sobie wyobrazić, że paliwa kopalne, w tym szczególnie węgiel, będzie tym surowcem energetycznym, na którym będziemy budować przyszłość. Ciemna energia i ciemna materia to dzisiaj wyzwanie dokładnie takie samo jak elektryczność i magnetyzm w czasie Newtona, jak podróż Kolumba do Indii, ale nasze dzieci chca podróżować i oczekują braku barier energetycznych. Stąd w naszej ocenie powoli nadciaga era (pokolenie wodoru), która będzie mostem energetycznym dla cywilizacji międzygwiezdnej, galaktycznej, dla cywilizacji, która nie będzie oparta na ziemskich surowcach kopalnych, a na energii z ciemnej energii lub ciemnej materii.

Warto popatrzeć na sektor energetyczny z nowej perspektywy i odpowiedzieć sobie na pytanie z pragmatyczną szczerością: O co walczymy? Jakie jest miejsce Polski w energetycznej europejskiej układance?

\section{Bibliografia}

[1] Ministerstwo Energii (2018), Polityka Energetyczna Polski do 2040 roku (PEP 2040), https://www.gov.pl/documents/33372/436746/PEP2040_projekt_v12_201811-23.pdf/ee3374f4-10c3-5ad8-1843-f58dae119936 
[2] ft//rzw (2018), Dokument końcowy szcrytu klimatycznego w Katowicach prayjety, TVN24, https://www.tvn24.pl/wiadomosci-ze-swiata,2/cop24-strony-przyjelydokument-koncowy-szczytu-w-katowicach,892704.html

[3] Sikora A. (2019), Dopokad..., „Chemia Przemysłowa” nr 1/ (716)

[4] Ustawa z dnia 28 grudnia 2018 r. o zmianie ustawy o podatku akcyzowym oraz niektórych innych ustaw, Dz.U. 2018 poz. 2538

[5] awi, aleBank.pl (2019), Prezes URE: Ustawa ws. cen pradu powinna być pilnie znowelizowana, aleBank.pl, https://alebank.pl/prezes-ure-ustawa-dotyczaca-cen-energiielektrycznej-powinna-byc-pilnie-znowelizowana/

[6] Soroko T. (brak roku), 20 pytań o nowa ustawe $i$ ceny energii, https://www.linkedin.com/pulse $/ 20$-pyta $\%$ C5\%84-o-now $\%$ C4\%85-ustaw $\%$ C4\%99-i-ceny-energii-tomasz-soroko/

[7] WNP.PL (Ireneusz Chojnacki) (2019), Piotr Zawistowski: Trzeba nowej koncepcij bandlu energia w Polsce, wnp.pl, https:// energetyka.wnp.pl/piotr-zawistowski-trzebanowej-koncepcji-handlu-energia-w-polsce,338538_1_0_0.html

[8] Świrski K. (2019), PEP 20140 - cay rozwiqzuje wssystkie problemy? Sžersza analiza, Konrad Świrski Blog, http://konradswirski.blog.tt.com.pl/pep-2040-rozwiazuje-wszystkie-problemy-szersza-analiza/

[9] Najwyższa Izba Kontroli (2018), Rozwój sektora odnawialnych źródet energii, Informacja o wynikach kontroli, KGP.430.022.2017, Nr ewid. 171/2017/P/17/020/KGP, https://www.nik.gov.pl/plik/id,18357,v,artykul_17275.pdf

[10] Główny Urząd Statystyczny (2018), Energia ze śródet odnawianych w 2017 r., https://stat.gov.pl/obszary-tematyczne/srodowisko-energia/energia/energiaze-zrodel-odnawialnych-w-2017-roku,10,1.html

[11] Sikora M.P. (2018), Energetyka jadrowa na śniecie - stan w końcu 2018 roku, „Bezpieczeństwo Jądrowe i Ochrona Radiologiczna. Biuletyn informacyjny Państwowej Agencji Atomistyki" nr 4, https://www.cire.pl/pokaz-pdf-\%252Fpliki\%252F2\% 252F2018\%252Fmateusz_sikora_biuletyn_paa.pdf

[12] Ministerstwo Energii (2018), Wnioski z analiz prognostycznych dla sektora energetycznego - załącznik nr 1 do Polityki energetycznej Polski do 2040 roku, (PEP2040), https://www.gov.pl/documents/33372/436746/Wnioski_z_analiz_do_PEP2040_2018-11-23.pdf/1481a6a9-b87f-a545-4ad8-e1ab467175cf 
[13] Rada Ministrów (2009), Polityka energetycz̧na Polski do 2030 roku, M.P. z 2010 r. nr 2, poz. 11, https://www.gov.pl/web/energia/polityka-energetyczna-polski-do-2030-roku

[14] Schnell Ch. (2018), C\{y PEP 2040 to strategia energetyczna? (ANALIZA), BiznasAlert.pl, https:/ / biznesalert.pl/pep-2040-strategia-energetyczna-analiza/

[15] Ministerstwo Energii (2019), Projekt Krajowego planu na rzeecz energii i klimatu na lata 2021-2030, https://www.gov.pl/web/energia/projekt-krajowego-planu-na-rzecz -energii-i-klimatu-na-lata-2021-2030

[16] Biały R., Janusz P., Laciak M., Sikora A., Sikora M., Szurlej A. (2018), Petrochemia staje sie siła napedowa wykorzystania ropy naftowej i odbiorca nadwyżek gazu plynnego, „Przemysł Chemiczny” nr 12, DOI: 10.15199/62.2018.12.13

[17] Schmidt G. (2004), Methane: A Scientific Journey from Obscurity to Climate Super-Stardom, The NASA Goddard Institute for Space Studies, https://www.giss.nasa. gov/research/features/200409_methane/

[18] Seafloor mounds (2015), https://commons.wikimedia.org/wiki/File:Seafloor_mounds.jpg

[19] Klima K., Sikora A. (2016), W sqechobecny. Mamy wodór i co dalej...?, cz. 1, „Energetyka Cieplna i Zawodowa" nr 2 (628)

[20] Klima K., Sikora A. (2016), Zamknieta w wodorze. Mamy wodór i co dalej...?, cz. 2, „Energetyka Cieplna i Zawodowa” nr 36 (634) 